\title{
METHOD OF COMPARISON AND AXIOLOGICAL APPROACH TO THE STUDY OF MOVIES OF THE ACTORS OF KHARKIV SCHOOL
}

\section{Gorelova Viktoriya ${ }^{1}$}

DOI: https://doi.org/10.30525/978-9934-571-89-3_69

The main goal of the method of comparison, researchers V. Sheyko, N. Kushnarenko, are defined as follows: "Comparison is one of the most common methods of cognition. This is the process of establishing similarities or differences between objects and phenomena of reality, as well as finding a common, inherent in two or more objects".

Therefore, for the deep analysis and comprehension of the movie theaters of Kharkiv's actors in our study, the method of comparison was used extensively. For example, to compare images: in the film "The Poem about the Sea", actors L. Tarabarinov and E. Bondarenko embody two antipodes that symbolize the Sea and Earth, which interact with each other and can not exist without one. And in Kumanchenko's and Krynitsky's images of mothers, we can clearly see the relationship with natural phenomena like Mother-Earth, the mental organicity of existence in the natural environment and work with imaginary symbols such as horse harness. We also compared the Kyiv and Moscow acting schools, the hero L. Tarabarinov with the literary hero Don Zhuan, and so on. The images of the mercenary and serfs performed by B. Stavytsky and I. Zhilin were also analyzed by the comparison method and the contrast between the character of the heroes and their actions in almost identical circumstances, as expressed in the performances of both actors, was revealed. Actors build a score of their characters to the opposite of each other qualities - infantilism and determination. Also, the method of comparison helped to understand the acting decision of $\mathrm{O}$. Litskanovich in the role of divorce Marusy and betrayed by the bride Tamara, which is also based on the contradiction, but characteristic to the actress in the manner of the game, which is based on the similarity with the behavior of the snake.

According to the definition of the same researchers V. Sheyko, N. Kushnarenko, we understand the essence of the axiological approach: "Axiological (value) approach is based on the notion of value and makes it possible to find out the qualities and properties of objects, phenomena, processes capable of meeting needs an individual and a certain society, as well as ideas and motives in the form of a norm and an ideal" [1, p. 71].

In the dissertation, we consider the following values of the Ukrainian people as traditions, the old way of life, earth, family, house (hata), white vyshyvanka (soul), space, philosophy, personality, nature, humanism. By the way, the natural interpretation of the cinematic images through the connection with the elements and the organic existence in the natural environment is distinguished by the Kharkiv

\footnotetext{
${ }^{1}$ Kharkiv State Academy of Culture, Ukraine 
actor's school, which tends to the humanistic direction. Also, we refer to the national values of the continuity of generations in the transfer of knowledge in the field of art, in particular, it refers to the actor's and director's knowledge, which are represented by the "school of corsets", "the school of Kurbas" and continued in movie theaters of Kharkiv acting school.

The methodological basis of scientific research is the principal position of the researcher. Thus, based on the methodological foundations of scientific research, we were able to answer clearly the questions about: the supposed leading scientific idea, the essence of the phenomena of the Kharkiv theater school and Ukrainian cinema, including the poetic, contradictions that arise during the research, stages, stages of development, trends. This is the scientific concept of our study.

In the future, a more thorough understanding of the specifics of the work of the Kharkiv school actors is planned on the basis of the substantiation of the currently neglected cinematic samples of Ukrainian cinema with the participation of Kharkiv artists.

\section{References:}

1. Sheyko V., Kushnarenko N. (2008). Organizatsiya ta metodyka naukovo-doslidnytskoi diyalnosti, Kyiv: Naukova dumka. (in Ukrainian) 